\title{
The Use of Repair Request Strategies in Developing Communicative Skills Among Primary Stage Pupils
}

\author{
Dr. Fatma S. Mohamed \\ Professor of EFL Curricula \\ and \& Instruction Faculty of Education \\ Benha University \\ Sadek59@gmail.com
}

\author{
Dr. Doria T. Abdallah \\ English Language Teacher \\ dodi_abdo2000@yahoo.com
}

\section{Abstract}

The purpose of this study was to investigate the effectiveness of using repair request strategies for developing communicative skills among primary stage pupils. The participants were sixty pupils in fifth year from El-Shobban AlMuslimeen Language School in Benha at Quliobeya Governorate. The participants of the study were divided into two groups, the experimental group $(\mathrm{N}=30)$ and the control group $(\mathrm{N}=30)$. The communicative pre test was administered to the participants before the treatment. Then, the experimental group was taught repair request strategies while the control group was taught using the traditional method. Then the communicative post test was administered to both groups. Results of the study revealed that the program using repair request strategies was effective in developing communicative skills among the primary stage pupils.

Key words: repair request strategies and communicative skills. 
Dr. Fatma S. Mohamed

Dr. Doria T. Abdallah

$$
\begin{aligned}
& \text { " استخدام استراتيجيات الطلب المعدل لتنمية مهارات الإتصال } \\
& \text { في اللغة الإجليزية لاى تلاميذ المرحلة الإبتدائية " } \\
& \text { د. درية تمير عبدالله } \\
& \text { أ.د. فاطمة صادق محعد } \\
& \text { مُدـرسة لغة انجليزيـة } \\
& \text { أستاذ المناهـج وطرق تدريس } \\
& \text { اللغة الإنجليزية كلية التربية } \\
& \text { جامعتة بنها }
\end{aligned}
$$

ماخغص الادراسة

هدفت الدراسـة الحالية لتحديد فاعليـة استخدام استراتيجيات الطلب المعدل لتنميـة مهارات الإتصال يِ اللغـة الإنجليزية لدي تلاميذ المرحلة الإبتدائية. تكونت عينة الدراسـة من •7 طالباً بهدرسـة الشبـان المسلهـين للغات ببنها بهـحافظة القليوبية. تم تقسيهم العينـة إلى مجموعة تجريبية وعددها .ب طالباً ومجموعة ضابطة وعددها . r

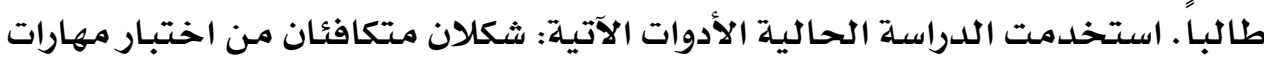
الإتصال ِِ اللخة الإنجليزيـة (من إعداد الباحثة) ، وأداة لتصحيحهـ تم تطبيق إختبار مهارات الإتصال يْ اللغـة الإنجليزيـة قبل وبعد تطبيق الإستراتيـيـات. أظهرت نتائج الدراسة فاعلية تطبيق الإستراتيجيات المقترحة فى تنهية مهارات الاتصال فِ اللخة الإنجليزيـة لدي تلاميذ المرحلة الإبتدائيـة ، حيث إن نتائج المجموعة التجريبيـة كانت أفضل من نتائحج المجموعة الضـابطة فى مهارات الإتصسال يِ اللخة الإنجليزيـة.

$$
\text { الكلمات المفتاحية : استراتيجيات الطلب المعدل ، مهارات الإتصال }
$$




\section{Introduction:}

Generally, studies that examine communicative repair requests describe a broad response class of spoken behaviors (i.e., behaviors that are topographically different, but produce the same effect). Each member of the "communicative repair request response class" provides an overt signal that a breakdown has occurred and continues the interaction. Examples include: (a) general requests for clarification (e.g., "What"), (b) specific requests for clarification (e.g., "Which green one?"), (c) statements specifying insufficiency or correcting an error (e.g., "Not the dog, you mean the cat.") and (d) general statements indicating lack of comprehension (e.g., "I don't understand.").

A common hierarchy of different repair request behaviors has not been adopted across studies. Porter and Conti-Ramsden (1987) described McTear's (1985) hierarchy of clarification request strategies that progress from those that are more ambiguous (e.g., non-specific request for repetition, for example, "What?" or "Huh?") to those that are the least ambiguous (e.g., you mean + specific request for confirmation, for example, "Do you like the black dog?" "You mean the brown dog?"). Other investigators have collapsed various repair behaviors into one broad category. For example, Abbeduto et al. (2008) described five different verbal repair behaviors (i.e., request for confirmation, request for definition, request for specific information, statement of existence, statement of nonexistence) and collapsed them for analysis into one general category (i.e., non-comprehension signals).

Beyond the absence of an established hierarchy of repair behaviors, researchers vary in their use of terminology, with some studies describing non-comprehension signals and other$$
-375-
$$ 
studies describing clarification requests. Broadly, a communicative repair request provides an overt signal that a breakdown has occurred (Dollaghan, 1987). Initiating requests for communicative repair requires that children engage in two behaviors. First, children must engage in comprehension monitoring, or the metacognitive skill in which they reflect on their understanding (i.e., their basic comprehension) of their partner's utterance (Dollaghan, 1987). Second, when they do not understand, they must signal this to their social partner to begin the process of communicative repair (Dollaghan, 1987). Comprehension monitoring refers to the ability to detect and address breakdowns in one's own understanding of language (Dollaghan, 1987; Markman, 1979). During comprehension monitoring, children must discriminate when they do and do not understand their social partner's communication. Thus, comprehension monitoring is the process by which persons think about their own understanding. During a social exchange, comprehension monitoring allows children to detect parts of the verbal and non-verbal communication act that they may not understand and then act. The term non-comprehension signaling connotes the process of comprehension monitoring, in which children reflect on their own understanding of their partner's utterance. This paper will use the term repair requests to encompass signals of non-comprehension and clarification requests.

Studies addressing communicative repair have focused either on how children initiate (i.e., produce unprompted) repair requests or how they respond to their social partner's repair request. Children's responses to adults' repair requests have received more attention in the communication repair literature. This project focuses on how children produce unprompted 
repair requests. The next section will review how studies have typically examined children's productions of unprompted repair requests.

Generally, studies designed to examine children's productions of repair requests have relied on structured tasks (e.g., referential communication tasks, direction-following activities, cooperative games) or unstructured languagesampling tasks. In structured tasks, the researcher is in a speaker-role and the child is in a listener-role. This paradigm provides opportunities for children to listen to the researcher's spoke message (typically requests for action, such as, "Put the spoon under the box.") and produce unprompted repair requests when there is an insufficient information resulting in a communication breakdown (e.g., "Put the spoon under the box" [when there is a fork but no spoon available in an array of objects]). In unstructured language sampling tasks, the researchers may vary the social partner interacting with the participants (e.g., caregiver, peer, or clinician). In language sampling tasks, opportunities to request repair are generally not systematically implemented but instead occur naturally following a communication breakdown. For example, during a play-based task between an adult and a child, the adult may request information from the child (e.g., "What is your car doing?") and the child may not have comprehended the adult and may initiate a communicative repair via a request for repetition (e.g., "What?").

Typically-developing (TD) children demonstrate some ability to both monitor their comprehension and request communicative repair between age 2 and 3 years (Aviezer, 2003; Pea, 1982; Revelle et al., 1985) with skill development continuing throughout the early school years (Beal \& Belgrad, 1990; Bonitatibus, 1988; Patterson et al., 1981). Revelle et al. 
(1985) examined repair requests of 3- and 4-year-old TD children, noting that by 4 years of age, children "demonstrate appropriate and discriminative comprehension monitoring" (P.662). In Julien's study (2018), the researcher engaged the participants using two structured, play-based tasks; one in which they played together in a sandbox and the other created a tea party. Experimental opportunities occurred when the researcher requested that the participant bring specific items to the researcher (i.e., "Bring me the teacup."). problematic requests included one of three types: referential ambiguity (i.e., several available objects could potentially fulfill the examiner's request), unintelligibility (i.e., examiner yawned while naming the referent in the request), and memory overload (i.e., examiner requested a list of 5 items for the child to bring).

The researcher also implemented control requests that were non-problematic and described as "easy to comprehend and comply with" (p.656). A total of 36 opportunities (18 problematic and 18 control) were implemented across the two structured tasks. Results revealed that 4-year-old children produced repair requests significantly more frequently than 3year-old children for each of the three types of problematic requests. Moreover, compared to 3-year-olds, 4-year-olds were significantly more likely to produce problem-focused responses (i.e., repair requests that highlighted the nature of the ambiguity, for example, "Which one?") following ambiguous examiner requests. Both groups produced significantly more problemfocused responses following the unintelligible examiner requests compared to the control requests.

Flavell et al. (1981) compared 6- and 9-year-old children in their detection of inadequate, ambiguous, inconsistent, and overly complex information. During a structured activity in 
which participants were assembling a specific block construction, the researchers presented spoken instructions. Inadequate instructions contained an unknown key word or a key word that had been masked by a noise (e.g., examiner cough). Ambiguous instructions contained an unclear referent, which allowed the participants to construct more than one possibility with their materials. Inconsistent messages contained contradictory information. Overly complex instructions were complete (meaning they could have been executed with the materials and language provided) but placed a high demand on the participants' memory because the instructions were very long. The study demonstrated that 9-year-old children were significantly more likely to detect inadequate, ambiguous, inconsistent, and overly complex instructions compared to the 6year-old children. In addition to the group level differences in detection, the older children were more likely to verbally respond and pause after detecting an issue in the information provided to them than the younger children.

Morisseau et al. (2013) investigated the responses that 3and 5-year-old children produced after hearing over- and underinformative verbal directives compared to optimal verbal directives. An adult examiner directed participants to locate one object from an array of 15 that were arranged on a $4 \times 4$ grid and place it in the empty grid location. The investigators examined children's spoken requests for clarification, non-spoken responses (i.e., direct gaze toward examiner after an underinformative directive), and response items. There were significant differences between younger and older children in the total number of communicative repair requests they produced. On average, the younger children requested clarification verbally and/or nonverbally following $25 \%$ of under-informative opportunities; whereas, the older children 
requested clarification for $50 \%$ of under-informative opportunities.

The 3-year-olds did not demonstrate significant differences in their reaction times after hearing over-informative directives compared to optimal directives. The 5-year-olds demonstrated significantly longer reaction times after hearing overinformative directives compared to optimal directives. Morisseau et al. noted that the 5-year-olds may have demonstrated longer reaction times after hearing overinformative directives because their expectations about how much information was needed to locate a specific item were violated. The 5-year-olds expected directions to be informative and the inclusion of redundant information was enough to slow their reaction time. It is possible that the 3 -year-olds did not have sufficiently strong expectations about how informative their social partner's message should have been. Available evidence suggests that comprehension monitoring and initiating requests for communicative repair are skills that emerge as early as 3 years of age and continue to develop as children's communication and cognitive skills become more sophisticated.

Factors Affecting the Production of Repair Requests

The available literature suggests that our understanding of the developmental trajectory of comprehension monitoring and requests for communicative repair appears to be influenced by the task in which these skills are assessed (Dollaghan, 1987; Revelle et al., 1985). A few studies have highlighted different vaiables' influence on the likelihood of repair requests, including the type of insufficient information, the social setting in which the information is presented, the relationship between 
social partners, and the function of the utterance that precedes the communicative repair request.

\section{Type of insufficient information}

Markman (1979) reported that school age children detected approximately $50 \%$ of the actual inconsistencies in a partner's provision of information. Markman examined 8- to 12-year-old children's comprehension monitoring by measuring their ability detect inconsistencies in non-fiction stories presented verbally. Children were divided into a younger group (mean age $=8$ years; 8 months) and an older group (mean age $=12$ years; 0 months). The stories contained either implicit or explicit contradictory information. For example, in the implicit condition, the story would describe fish that live in very deep water where there is no light and they know their food by its color. In the explicit condition, a similar story was presented with additional cues, for example, "fish need light in order to see" and "when it is dark fish can not see" (p. 646).

There was a significant difference between the explicit and implicit conditions. Results revealed that participants in both the younger age group and the older age group demonstrated difficulty detecting both implicit and explicit contradictions, with about $80 \%$ of children failing to detect an inconsistency in the implicit condition, and 50\% in the explicit condition. When the researchers provided a spoken prompt (i.e., "There is something tricky about these essays") prior to reading the story, the older children improved their performance. The older group performed significantly better than the younger group (and this difference was statistically significant) with about $12 \%$ of the older group failing to detect an inconsistency in each of the explicit and implicit conditions, while $75 \%$ of the younger children failed to detect inconsistency in the implicit condition 
and $50 \%$ of younger children failing to detect an inconsistency in the explicit condition.

Beyond information that contains explicit versus implicit contradictions, children's repair responses to other types of insufficient information have also been studied. Walters and Chapman (2000) examined children's spoken clarification requests following inadequate instructions that contained inadequate content, an inadequate signal, or were overly complex. An example of inadequate content was, "Put the spoon in the bowl," in which one of the referents was absent. An example of inadequate signal was, "Put the (cough) in the cup," in which there was an interruption to the acoustic signal. An example of an overly complex experimental opportunity was, "Do these things in the order I say them, but wait until I finish talking. First, put the girl in the car; then put the spoon in the cup, then pick up the box; then the car; then the spoon; and then the cup," (p.54). Participants were 3-, 6-, and 9-year-old children who listened to the pre-recorded verbal instructions and were asked to complete the instructions using small objects. An examiner indicated that participants could ask questions if they did not understand. If children requested clarification from the examiner, the examiner indicated that the talker "must have missed some information".

No statistically significant group differences were observed in the average number of spoken queries produced by 3 -yearolds, 6-year-olds and 9-year-olds across the three types of insufficient messages, suggesting the lack of a developmental effect. Across age groups, inadequate content messages were most frequently queried compared to complex/lengthy or distorted content messages. Walters and Chapman (2000) suggested that "sociability with adults" (p.53) might have 
accounted for differences in comprehension monitoring and requests for communicative repair across learners. The authors did not further operationalize this potential social variable.

They also suggested that requesting clarification following pre-recorded audio messages (as was used in this study) is likely different from requesting clarification during a face-to-face interaction. A limitation of this study was that the investigators did not directly examine the influence of the children's social competence or mode of presentation (e.g., were participants more likely to request repair when instructions were presented by a familiar versus unfamiliar adult or when instructions were presented via a recording versus during a real-time interaction with an adult) on participants' performance.

Additionally, the researchers included a measure of how the participants' mothers provided communicative feedback to their children. The participants' mothers listened to short stories that described a hypothetical situation in which their child struggles to understand how to do something. The researchers then prompted the mothers to describe how they might support their child in this situation. The responses were coded for : (a) directing the child's attention to the specific communication exchange, (b) suggesting a strategy for resolving their confusion, (c) intervening for the child, and (d) not intervening and allowing child to work through confusion independently.

Function of social partner's communicative utterance

The function of the adult's utterance may also be an influential variable in examining repair requests. The majority of repair request studies have relied on adult/researcher utterances that are requests for action, information, or objects. The function of these utterances creates an obligatory opportunity for the child to respond. There is little evidence 
examining children's repair requests following adult utterances that are comments or provision of information. The function of these utterances renders the child's response to be nonobligatory because a response is not required or expected.

Webber et al. (1984) reported that TD children aged 3 to 9 years old queried their adult social partner after she had produced a comment with an ambiguous referent during an interaction. In this study, participants were presented with 10 experimental communicative bids during unstructured play. Seven of the communicative bids were non-obligatory and contained an ambiguous referent. For example, "I have a liki at home". Three of the bids were questions and were considered to place a social expectation on the child to respond. Like the comments, the questions contained an ambiguous referent, for example, "Do you know that story?" Webber et al. noted that participants at ages 3,5,7 and 9 years produced repair requests following the ambiguous information for at least $50 \%$ of opportunities.

This provides some evidence that children across a wide age range may produce requests for communicative repair in nonobligatory communicative contexts. The authors did not report analyses related to differences based on participants' age. More broadly, there is little published information from the Webber et al. (1984) study regarding more specific methodological details and analyses; thus, the results must be cautiously interpreted. Despite the lack of specific published details, the study has been included in the literature review given the limited available evidence related to repair requests following non-obligatory opportunities. 
Perspective-taking abilities may be influential in children's ability to engage in communicative repair requests. In order for repair requests to be successful (i.e., to mitigate or eliminate the misunderstanding within the interaction), a speaker may have to craft their repair based on their understanding of their social partner's knowledge. That is, the repairer may have to understand the conversation and account for their social partner's perspective (which may differ from their own).

\section{A: The Basics of The Repair Requests}

Theory of mind is the ability to assign mental states to oneself and to others and to use knowledge of mental states to predict others' behavior (Premack \& Woodruff, 1978). Mental states are not directly observable and may include beliefs, preferences, and intentions. Research related to theory of mind development has received much attention in the developmental psychology literature over the past 40 years (for reviews see Flavell, 2000; Flavell; 2004; Repacholi \& Slaughter, 2003). Among preschool age children, researchers have documented development in visual perception, attention, understanding emotions and desires, and continued engagement in pretendbased play as factors closely linked to the theory of mind development (Flavell, 2000).

Theory of mind tasks are often categorized as first-order belief tasks or second-order (and higher) belief tasks. First-order belief tasks ostensibly assess a child's understanding of what other people think about reality. Second-order belief tasks assess a child's understanding of a person's beliefs about another person's beliefs about reality (Perner \& Wimmer, 1985). Children begin to pass second-order belief tasks in their early school years (e.g., Perner \& Wimmer; 1985). Various criterionreferenced assessments of theory of mind have been developed,

\section{$-385-$}


including the location-change false belief task (e.g., Wimmer \& Perner, 1983; Baron-Cohen et al., 1985), the unexpectedcontents false belief task (e.g., Hogrefe, Wimmer, \& Perner, 1986), and evaluation of lies and jokes task (e.g., Sullivan, Winner, \& Hopfield, 1995).

The location-change false belief task (sometimes referred to as the "Sally-Ann" task; Barron-Cohen et al., 1985) utilizes a puppet show format with two main characters who are playing with toys. One character hides a toy and then leaves the scene, and then the second character moves the toy to a new location. When the first character returns, children are asked if the first character knows where the toy is and where the character will look for the toy. Stronger theory of mind skills are attributed to children who are able to indicate that the first character will not know where the toy has been hidden.

The unexpected-contents false belief task (sometimes called the "Smarties" task; Hogrefe et al., 1986) invites children to watch an examiner hold a familiar container (e.g., a crayon or candy box) that has been filled with unexpected contents (e.g., crayon or candy box filled with paper clips). The examiner asks the child what the child thinks is in the box, then reveals that the box contains something different from what the child predicted. Finally, the examiner asks the child if a caregiver (not present) will know what is inside the container and what their caregiver will state is inside. Stronger theory of mind skills are attributed to children who indicate that their caregiver will not know the unexpected contents (as they have not yet seen them as the child has) and will state that the expected item (e.g., crayons or candy). 
The lies and jokes task asks children to evaluate whether a child character's statement (e.g., "I did a good job eating my peas.") is a lie or a sarcastic joke, based on an adult character's knowledge (Steele, Joseph, \& Tager-Flusberg, 2003). Stronger theory of mind skills are attributed to children who are able to able justify whether the child character's statement was a lie or a sarcastic joke based on whether the child character knows the adult character's knowledge of the truth.

Among TD children, empirical evidence suggests a positive link between performance on theory of mind assessments and real-time social behavior (for a review, see, Repacholi \& Slaughter, 2003). For example, Watson, Nixon, Wilson, and Capage (1999) demonstrated that 3- to 6-year-old children's false belief understanding predicted teachers' ratings of "the extent to which children engaged in social interactions with peers," (p., 387), after controlling for age, language comprehension, and overall talkativeness with peers. Flavell (2004) broadly noted that children who have more advanced understanding about others' minds tend to experience more successful social relationship.

With respect to repair requests, Feldman and Kalmar (1996; as cited by Bosco \& Gabbatore, 2016) first described the link between theory of mind and the ability to engage in communicative repair in discourse. They noted speakers might consider their conversation partner's knowledge and intentions and adjust their own accordingly. When misunderstandings and requests for clarification (i.e., repairs) occur, a child is presented with an opportunity to understand discourse from more than one perspective because a request for repair is a signal that one social partner understands the content of the discourse differently from the other social partner. Tomasello (1999) suggested that a child's experience with this type of discourse 
(i.e., a misunderstanding and later repair) facilitates the development of theory of mind (and other social knowledge), as a child must reconcile two different perspectives.

Recent studies rooted in Cognitive Pragmatics suggest a positive relationship between TD children's development of theory of mind and their abilities to recognize and repair communication failures (see Bosco et al., 2006; Bosco \& Gabbatore, 2016). Work in this area has focused on communication failures from the speaker's perspective. Typically, in these studies, the researcher creates opportunities for children to identify when communication failures have occurred (i.e., the children watch a short video-recorded interaction between two people) and to indicate how the speaker depicted in the video-recorded interaction might repair their initial utterance.

Bosco and Gabbatore (2016) found that theory of mind task performance had a positive relationship with TD children's ability recognize communication failures in a structured task. In this study, children aged 3 years; 6 months to 8 years; 5 months watched $15 \mathrm{~s}$ video clips of people engaged in a short conversation. For example, the speaker asks her conversational partner, "Do you want to take a walk" but a loud bus is passing near them. The conversational partner says, "What did you say?" Researchers asked the participants whether the listener had understood what the speaker said (i,e., was there a communication failure). If the child indicated that a failure had occurred, the researcher prompted the child to describe how the speaker might respond to the communication failure.

Our understanding of communicative repair has focused primarily on how children respond to an adult's intentional 
creation of a communication breakdown (e.g., if an adult fails to comply with a child's request for a specific toy [or provides the wrong toy] or the adult request for clarification after a child's utterance). Less attention has focused on how children initiate communicative repair requests when presented with an insufficient communicative opportunity (e.g., when an adult provides ambiguous instructions). Moreover, the majority of investigations related to typically-developing (e.g., Flavell et al., 1981; Morisseau et al., 2013; Revelle et al., 1985; Walters \& Chapman, 2000) and a typically-developing (e.g., Abbeduto et al., 2008; Abbeduto et al., 1997; Brinton \& Fujiki, 1982; Dollaghan \& Kaston, 1986; Ezell \& Goldstein, 1991; John et al., 2009; Skwerer et al., 2013) children's communicative repair requests have relied on tasks presented via an obligatory communicative opportunity in which the speaker's message contains inadequate information. For example, participants are asked to follow verbal directions in which the content is degraded (e.g., examiner states, "Put the (cough) in the cup.") or ambiguous (e.g., examiner states "Bring me the cup" in the presence of multiple cups).

Very few studies (Webber, Fey, \& Disher, 1984) have examined non-obligatory communicative opportunities that do not necessarily require that the participant respond to the examiner (e.g., "I like the blue one" when there are multiple blue items in an array). Non-obligatory opportunities allow more degrees of freedom for the child's response, for example, a child may request repair (i.e., "Which blue one?" or "This blue one?"), may maintain the interaction by mirroring the examiner's utterance (i.e., "I the blue one, too!"), may change the topic without repairing (i.e., "I like the red truck!"), or may attempt to infer the reference without repairing.

B: Request Strategies

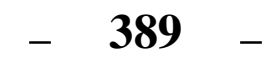


The choice of request strategy reflects a speaker's use of various structural and grammatical formulations in a request, which affects the directness level of the request (see Appendices).

\section{Background of the problem:}

In spite of the importance of communication skills, there is a lack in communication skills among primary school pupils. Thus there is a need for finding an effective instructional strategies for developing communication skills among primary school pupils.

In order to be fully sure of the problem of this study, the researcher conducted a pilot study including some texts. It requires students to read the text and answer questions that follow it. This test has been applied to twenty of fifth year primary school pupils. The results of this pilot study confirmed the low level of the pupils in communication skills. So, it is clear that there is a great need for developing communication skills among primary school pupils. This study used repair request strategies for developing communication skills among fifth year primary school pupils.

\section{Statement of the problem:}

The problem of the present research can be defined in the fifth year primary school pupils' inefficient communication skills. Therefore, the present study is an attempt to investigate the effectiveness of repair request strategies for developing the communication skills among fifth year primary school pupils.

\section{Questions of the Study:}

To face this problem, the present research is an attempt to answer the following questions: 
1- What are the repair request strategies for developing communication skills among fifth grade primary school pupils?

2- What is the effect of repair request strategies on developing communication skills among fifth grade primary school pupils?

\section{Delimitations of the Study:}

The current research is limited into the following:

- Sixty fifth graders of primary school in El-Shobban AlMuslimeen Language School in Banha, Qalioubiya Governorate, Egypt.

- Some communication skills required for the fifth year primary pupils.

\section{Hypotheses of the study:}

1. There are no statistically significant differences between the mean scores of the experimental group and the control group before the treatment in the communication skills test.

2. There are statistically significant differences between the mean scores of the experimental group in the pre- post test.

3. There are no statistically significant differences between the mean scores of the control group in the pre-post testing in communication skills. 
4. There are statistically significant differences between the experimental group and control group in the post test of communication skills in favor of the experimental group.

\section{Instruments and materials:}

To achieve the purpose of the study, two equivalent forms of communication skills test (prepared by the researcher), and a rubric for scoring them were used.

\section{Participants of the study:}

The participants of the present study consisted of 60 fifth year pupils from El-Shobban Al-Muslimeen Language School, enrolled in the academic year (2020-2021). Two intact classes were selected for participating in the study; class 5/A $(n=30)$ served as the experimental group and class $5 / \mathrm{B}(\mathrm{n}=30)$ served as the control group.

\section{Procedures of the study:}

After the participants in the research have been selected, The participants of the study were divided into two groups, the experimental group $(\mathrm{N}=30)$ and the control group $(\mathrm{N}=30)$. The pre communicative test was administered to the participants before the treatment. Then, the experimental group was taught using repair request while the control group was taught using the traditional method. Then the post communicative test was administered to both groups. Results of the study revealed that the program using repair request was effective in developing communicative skills among the primary school pupils . 
Educational and Psychological Studies Faculty of Education Journal Zagazig University Vol. (36) No. (113), Part(2), October 2021

Findings of the study:

The results of the research will be presented in the light of following hypotheses:

\section{1- Findings of the first hypothesis:}

The first hypothesis states that "there is no statistically significant difference between the control group and the experimental group before the treatment in the communication skills test".

To verify the equality of variances, the Levenl test was used and the independent t.test also, so the means were compared using a two-tailed t.test. The P-value was 0.357 which is bigger than 0.05 . Therefore, it was concluded that there were no significant differences between the mean scores of the two groups. The following table presents this:

Table ( 1 ) T-test between the mean scores of the experimental group and the control group in the communicative skills pre test

\begin{tabular}{|c|c|c|c|c|c|c|}
\hline Sig. & $\begin{array}{c}\text { Df } \\
\cdot\end{array}$ & $\begin{array}{c}\text { t- } \\
\text { valu } \\
\mathbf{e}\end{array}$ & $\begin{array}{c}\text { Deviatio } \\
\text { n }\end{array}$ & $\begin{array}{c}\text { Mea } \\
\mathbf{n}\end{array}$ & $\begin{array}{c}\text { No } \\
\cdot\end{array}$ & Group \\
\hline $\begin{array}{c}0.546 \\
3\end{array}$ & 6.0 & $\begin{array}{c}0 . \\
929\end{array}$ & 4.62 & 25.59 & 30 & $\begin{array}{c}\text { Experimenta } \\
1\end{array}$ \\
\cline { 4 - 7 } & & 5.20 & 42.43 & 30 & Control \\
\hline
\end{tabular}

It is clear from this table that the two groups are homogenous in terms of their communication skills. The following figure shows this: 
Figure (1): The mean scores of the experimental group and the control group in the communicative skills pre test

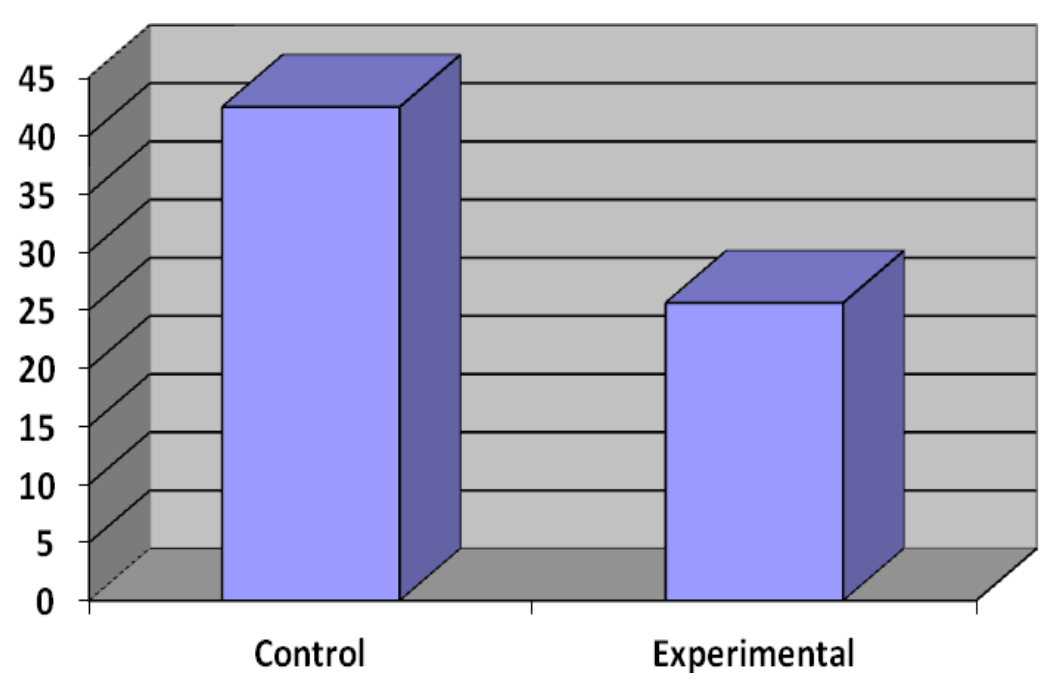

2- Findings of the second hypothesis:

The second hypothesis states that "there are statistically significant differences between the mean scores of the experimental group in the pre-post test".

To verify this hypothesis, Paired-sample t. test was used. The following table shows this:

Table (2) : T-test between the mean scores of the experimental group in the pre- post treatment.

\begin{tabular}{|l|l|l|l|l|l|l|}
\hline Sig. & $\begin{array}{l}\text { Df } \\
\cdot\end{array}$ & $\begin{array}{l}\text { t- } \\
\text { valu } \\
\mathbf{e}\end{array}$ & $\begin{array}{l}\text { Std. } \\
\text { Deviatio } \\
\mathbf{n}\end{array}$ & $\begin{array}{l}\text { Mea } \\
\mathbf{n}\end{array}$ & $\begin{array}{l}\text { No } \\
\cdot\end{array}$ & $\begin{array}{l}\text { Experimenta } \\
\mathbf{l}\end{array}$ \\
\hline 0.00 & 31 & 7.28 & 5.46 & 92.37 & 30 & Gost test \\
\cline { 4 - 7 } \\
\cline { 4 - 7 }
\end{tabular}


It is clear from this table that $\mathrm{P}$. value calculated to be 0.000 which is smaller than 0.05 indicating that there was a statistically significant difference between the means of the experimental group before and after treatment. The significance is due to the treatment intervention which is repair-request. The following figure shows this:

Figure (2): The mean scores of the experimental group in the pre- post treatment

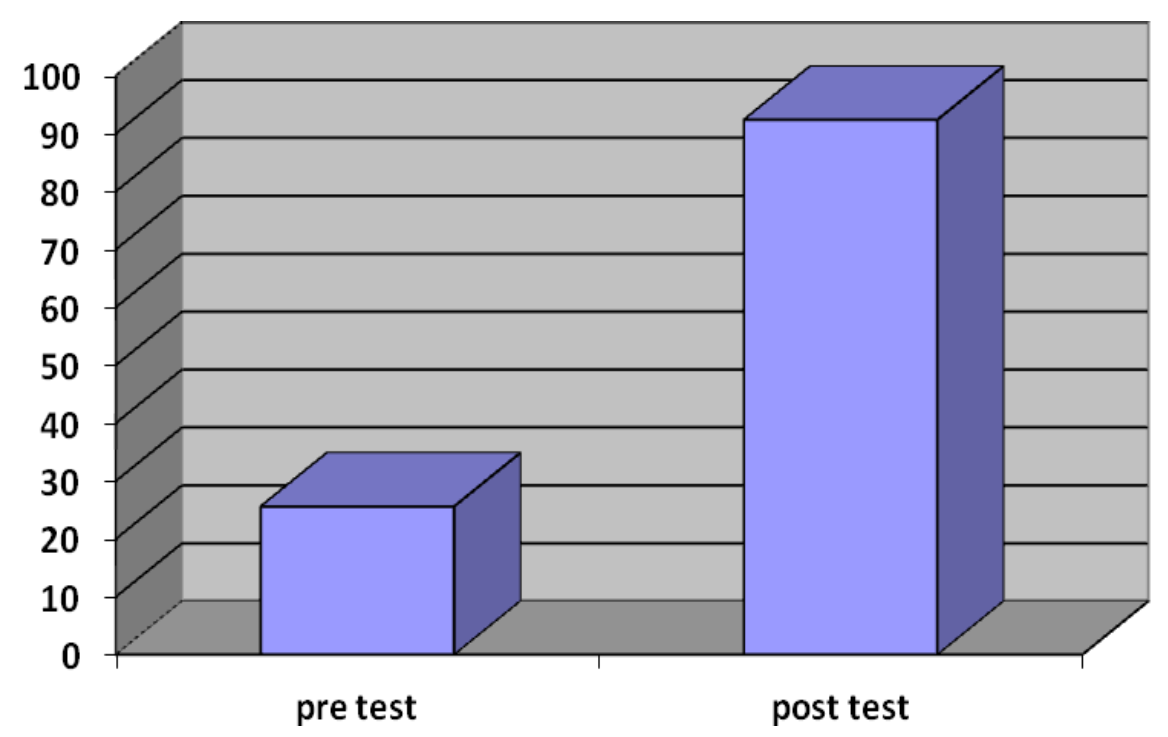

\section{Findings of the third hypothesis:}

The third hypothesis states that "there is no statistically significant difference between the mean scores of the control group in the pre-post testing in communication skills".

To verify this hypothesis, the matched t. test was used. P. value treatment turned out to be 0.724 which is bigger than 0.69 suggesting that there was no statistically significant difference between the mean scores of the pre-post tests. The following table shows this: 
Table ( 3 ) T-test between the mean scores of the control group in the pre-post tests of communicative skills

\begin{tabular}{|l|l|c|c|c|c|c|}
\hline Sig. & Df. & $\begin{array}{c}\text { t- } \\
\text { value }\end{array}$ & $\begin{array}{c}\text { Std. } \\
\text { Deviation }\end{array}$ & Mean & No. & $\begin{array}{c}\text { Control } \\
\text { Group }\end{array}$ \\
\hline 0.724 & 29 & 0. & 5.76 & 24.56 & 30 & Post test \\
\cline { 4 - 7 } & & 357 & 5.20 & 34.43 & 30 & Pre test \\
\hline
\end{tabular}

It is clear from this table that there is no statistically significant difference between the mean scores of the control group in the pre-post test of communication skills which is attributed to the fact that this group did not receive any kind of treatment. The following figure shows this:

Figure (3) : The mean scores of the control group in the pre-post tests of communicative skills

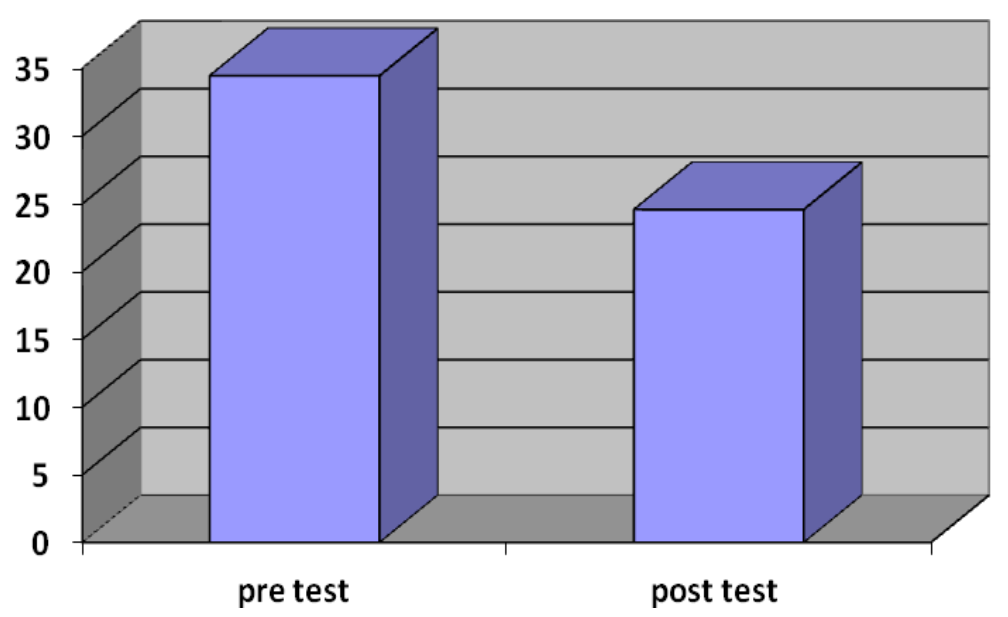

3- Findings of the third hypothesis: 
Educational and Psychological Studies Faculty of Education Journal Zagazig University Vol. (36) No. (113), Part(2), October 2021

The fourth hypothesis states that "there are statistically significant differences between the mean scores of the experimental group and the control group in the post test of communication skills".

To verify this hypothesis, a paired sample t. test was performed to compare the mean scores of the pupils in the two groups. The following table shows this:

Table ( 4 ) T-test between the mean scores of the experimental group and the control group in the post test of communicative skills

\begin{tabular}{|c|c|c|c|c|c|c||}
\hline Sig. & $\begin{array}{c}\text { Df } \\
\cdot\end{array}$ & $\begin{array}{c}\text { t- } \\
\text { valu } \\
\mathbf{e}\end{array}$ & $\begin{array}{c}\text { Std. } \\
\text { Deviatio } \\
\mathbf{n}\end{array}$ & $\begin{array}{c}\text { Mea } \\
\mathbf{n}\end{array}$ & $\begin{array}{c}\text { No } \\
\cdot\end{array}$ & Post Test \\
\hline 0.00 & \multirow{2}{*}{$\begin{array}{c}60 \\
1\end{array}$} & 3.63 & 5.46 & 92.37 & 30 & $\begin{array}{c}\text { Experimenta } \\
\text { l Group }\end{array}$ \\
\cline { 4 - 7 } & & 5.76 & 42.56 & 30 & $\begin{array}{c}\text { Control } \\
\text { group }\end{array}$ \\
\hline
\end{tabular}

It is clear from this table that there are statistically significant differences between the mean scores of the experimental group and the control group in the post test of communication skills. The level of significance is 0.001 . This significance is in favor of the experimental group. This can be due to the communication treatment interaction during the study. The following figure shows this: 
Figure (4) : The mean scores of the experimental group and the control group in the post test of communicative skills

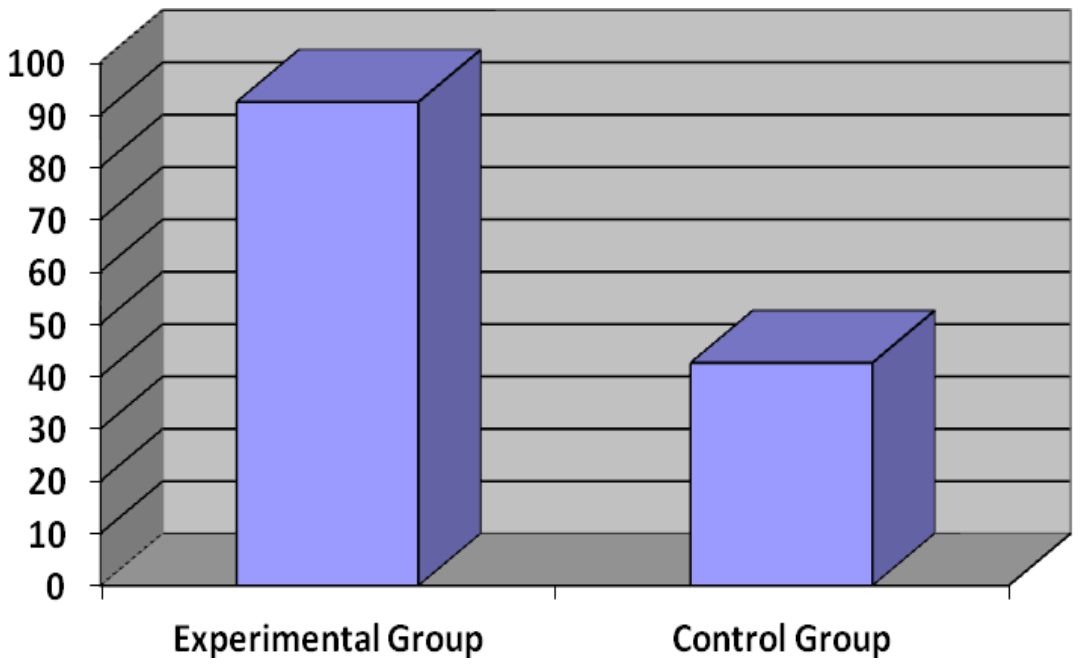

\section{Discussion of the results:}

The results of the present study showed that there are statistically significant differences between the mean scores of the pupils in the post treatments in the communication skills. The experimental group outperformed the control group in the communication skills in the post testing. This progress may be due to the fact that the treatment created opportunities for the pupils to practice repair request in a variety of context_request for information request for clarification, request for correction and feedback. This result is consistent with Julien (2018).

The results also indicated that the experimental group performance in the post treatment was higher than the pre treatment. This outperformance is attributed to the fact that pupils received and responded to the repair request in different communicative activities within interactions with the teacher which created opportunities for the pupils to better monitor 
their own comprehension and indicate when something seems to be confusing, then the participants in this study may have been likely to repair following the opportunities given to them because they have had more experience receiving feedback about responding and reproducing following request for information/action during natural social interaction. This result is consistent with Salih (2015).

The results also indicated that the experimental group pupils in the pre- treatment should lack the opportunities to practice repair request. After treatment there was significant difference in production of repair request following the different forms of communication tasks. This helped them to differentiate the different forms of request- repair for the situation Phaisarnsitthikarn (2020).

The results showed that the pupils performance in the communicative tasks based on repair request was greater in the post treatment than the pre one which may be due to the fact that the pupils were exposed to receptive and expressive communicative practice with the teacher in the treatment, the case which helped them better understand the relationship between receptive language abilities and requests. The teacher also focused on the participant level variables at play including attention, the pupil's interest in a particular topic and the pupils' experience with receiving instructional opportunities related repairing communication breakdown. The teacher provided the pupils with models to follow especially in utterance which gave them the opportunities to practice communicative repair. This result is consistent with Julien (2018).

One of the main reasons for the pupils progress in communication skills in the present study is that the study used the social partner during interaction which may influence repair request of the pupils in communication because the high level of the partner's responsibility may increase the likelihood that a 
pupil would initiate repair, moreover, the adequacy of social partner's repair may influence the likelihood of pupil's future repair request in communication. In the present study also the communicative practices depended on the social partner's familiarity and their communicative competence.

\section{Conclusion:}

The present research attempted to develop the EFL communicative skills among fifth year primary school pupils through the use of repair request. The results of the current research proved the effectiveness of repair request in developing communicative skills among fifth year primary school pupils. Therefore, repair request is recommended for fifth year preparatory pupils to develop their communicative skills.

\section{Suggestion for further research:}

Based on the results of the present study, the researcher can recommend and suggest :

- Studying the relationship between motivation and repair among elementary stage pupils.

- Studying repair skills in listening and speaking among elementary school pupils.

- Using dialogue- based tasks to increase communicative repair.

- Utilizing naturalistic tasks, structured tasks and scripted tasks to improve repair request communication.

- Studying the relationship between repair request production and use among primary school pupils. 


\section{References}

-Abbeduto, L., Murphy, M. M., Kover, S. T., Giles, N. D., Karadottir, S., Amman, A., \& Nollin, K. A. (2008). Signaling Non comprehension of language: A comparison of fragile $X$ syndrome and Down syndrome. American Journal on Mental Retardation, 113(3), 214-230.

-Abbeduto, L., Short-Meyerson, K., Benson, G., \& Dolish, J. (1997). Signaling of Non comprehension by Children and Adolescents with Mental Retardation Effects of Problem Type and Speaker Identity. Journal of Speech, Language, and Hearing Research, 40(1), 20-32.

-Aviezer, O. (2003). Bedtime talk of three-year-olds: Collaborative repair of miscommunication. First Language, 23(1), 117-139.

-Baron-Cohen, S., Leslie, A. M. \& Frith, U. (1985). Does the autistic child have a "theory of mind"? Cognition, 21(1), 3746.

-Beal, C. R., \& Belgrad, S. L. (1990). The development of message evaluation skills in your children. Child Development, 61(3), 705-712.

-Bonitatibus, G. (1988). Comprehension monitoring and the apprehension of literal meaning. Child Development, 95(1), 60-70.

-Bosco, F. M., Bucciarelli, M., \& Bara, B. G. (2006). Recognition and repair of communicative failures: $A$ developmental perspective. Journal of Pragmatics, 38(9), 13981429.

- Bosco, F. M., \& Gabbatore, I. (2016). Theory of mind in recognizing and recovering communicative failures. Applied Psycholinguistics, 1-32.

-Brinton, B., \& Fujiki, M. (1982). A comparison of requestresponse sequences in the discourse of normal and language- 
Dr. Fatma S. Mohamed

Dr. Doria T. Abdallah

disordered children. Journal of Speech and Hearing Disorders, 47(1), 57-62.

-Dollaghan, C. A. (1987). Comprehension monitoring in normal and language-impaired children. Topics in Language Disorders, 7(2), 45-60.

-Dollaghan, C., \& Kaston, N. (1986). A comprehension monitoring program for language-impaired children. Journal of Speech and Hearing Disorders, 51(3), 264-271.

-Ezell, H. K., \& Goldstein, H. (1991). Observational learning of comprehension monitoring skills in children who exhibit mental retardation. Journal of Speech, Language, and Hearing Research, 34(1), 141-154.

-Feldman, C. F., \& Kalmar, D. (1996). You can't step in the same river twice: Repair and repetition in dialogue. Repetition in Dialogue, Niemeyer, Tubingen, 78-89.

- Fey, M. E., Warr-Leeper, G., Webber, S. A., \& Disher, L. M. (1988). Repairing children's repairs: Evaluation and facilitation of children's clarification requests and responses. Topics in Language Disorders, 8(2), 63-84.

-Flavell, J. H. (2000). Development of children's knowledge about the mental world. International Journal of Behavioral Development, 24(1), 15-23.

-Flavell, J. H. (2004). Theory-of-mind development: Retrospect and prospect. Merrill-Palmer Quarterly, 50(3), 274-290.

-Flavell, J. H., Speer, J. R., Green, F. L., August, D. L., \& Whitehurst, G. J. (1981). The development of comprehension monitoring and knowledge about communication. Monographs of the Society for Research in Child Development, 46(5), 1-65.

-Hogrefe, G. J., Wimmer, H., \& Perner, J. (1986). Ignorance versus false belief: A developmental lag in attribution of epistemic states. Child Development, 57, 567-582. 
-John, A. E., Rowe, M. L., \& Mervis, C. B. (2009). Referential communication skills of children with Williams syndrome: Understanding when messages are not adequate. American Journal on Intellectual and Developmental Disabilities, 114(2), 85-99.

-Julien, H. M. (2018). Communicative Repair Requests produced by Typically-Developing Preschoolers and Preschoolers with Autism Spectrum Disorder. Doctoral Dissertation, Minnesota University, United States.

-Korkmaz, B. (2011). Theory of mind and neurodevelopmental disorders of childhood. Pediatric Research, 69, 101R-8R. doi: 10.1203/PDR.0b013e318212c177.

-Markman, E. M. (1979). Realizing that you don't understand: Elementary school children's awareness of inconsistencies. Child Development, 643-655.

-McTear, M. (1985). Children's conversation. Oxford, England: Blackwell Publishing.

-Morisseau, T., Davies, C., \& Matthews, D. (2013). How do 3and 5-year-olds respond to under- and over-informative utterances? Journal of Pragmatics, 59, 26-39.

-Patterson, C. J., O'Brien, C., Kister, M. C., Carter, D. B., \& Kotsonis, M. E. (1981). Development of comprehension monitoring as a function of context. Developmental Psychology, 17(4), 379.

-Pea, R. D. (1982). Origins of verbal logic: Spontaneous denials by two-and three-year olds. Journal of Child Language, 9(3), 597-626.

-Perner, J., \& Wimmer, H. (1985). "John thinks that Mary thinks that..." attribution of second order beliefs by 5-to 10year-old children. Journal of Experimental Child Psychology, 39(3), 437-471.

-Phaisarnsitthikarn, J. (2020). The development of pragmatic competence in request speech acts of Thai learners of English 
in study Abroad contexts. Doctoral Dissertation, Toronto University, United States.

-Porter, R., \& Conti-Ramsden, G. (1987). Clarification requests and the language-impaired child. Child Language Teaching and Therapy, 3(2), 133-150.

-Premack, D., \& Woodruff, G. (1978). Does the chimpanzee have a theory of mind? Behavioral and Brain Sciences, 1(4), 515-526.

-Repacholi, B. M., \& Slaughter, V. (Eds.). (2003). Individual differences in the theory of mind. New York: Psychology Press.

-Revelle, G. L., Wellman, H. M., \& Karabenick, J. D. (1985). Comprehension monitoring in preschool children. Child Development, 3(56), 654-663.

-Salih, S. (2015). Polite Requests As Speech Acts: A comparative study of Gender Variation of Native Speekers Students at the university level. Annals of the faculty of Arts, Ain Shams University, Vol.43, 547.

-Sidera, F., Perpina, G., Serrano, J., \& Rostan, C. (2016). Why is theory of mind important for referential communication? Current Psychology, 1-16.

-Skwerer, D. P., Ammerman, E., \& Tager-Flusberg, H. (2013). Do You have a question for me? How children with Williams syndrome respond to ambiguous referential communication during a joint activity. Journal of Child Language, 40(01), 266289.

-Steele, S., Joseph, R. M., \& Tager-Flusberg, H. (2003). Brief report: Developmental change in theory of mind abilities in children with autism. Journal of Autism and Developmental Disorders, 33(4), 461-467. 
-Sullivan, K., Winner, E., \& Hopfield, N. (1995). How children tell a lie from a joke: The role of second-order mental state attributions. British Journal of Developmental Psychology, 13(2), 191-204.

-Tomasello, M. (1999). The cultural origins of human cognition. Cambridge, MA: Harvard University Press.

-Walters, D. B. S., \& Chapman, R. S. (2000). Comprehension Monitoring: A Developmental Effect?. American Journal of Speech-Language Pathology, 9(1), 48-54.

-Watson, A. C., Nixon, C. L., Wilson, A., \& Capage, L. (1999). Social interaction skills and theory of mind in young children. Developmental Psychology, 35(2), 386.

-Webber, S. A., Fey, M. E., \& Disher, L. M. (1984). What's a grizic? Clinical sampling of children's contingent query behavior. Paper presented at the American Speech-LanguageHearing Association Convention, San Francisco, CA.

-Wimmer, H., \& Perner, J. (1983). Beliefs about beliefs: Representation and constraining function of wrong beliefs in young children's understanding of deception. Cognition, 13(1), 103-128. 


\section{Appendix (A) \\ Communicative Skills Pre-Test}

Name:

Class :

Dear pupils,

The following is a communicative test, try to respond to it, the way you understand.

\section{1-"Request" Situation}

You are at a restaurant with your Teacher and classmates, and you discover that you must have left your wallet at home because you were rushing to get to the restaurant on time. You don't have enough money to pay for your share of the bill and you are reluctant to ask your friend for 20 pounds; of course you would pay the money back as soon as possible, but she/he had just been complaining about his current cash flow problem. You mull it over in your mind for a while and finally decide to ask your friend for money in order not to feel embarrassed in front of your teacher. You say:

- Could you please lend me some money ? (Interrogative) 
You have money, don't you? (Question Tag)

Did you leave your money too? (Past simple)

Would you mind giving me current cash flow? (Embedded "if" clause)

Deciding to give me money, will it be o.k.? (ing forms conditional)

\section{2-"Request" Situation}

You are discussing an assignment with your new teacher, who has just moved to your class in your school. It is the first time you have met him. He speaks very fast and uses a lot of technical terms that you don't understand. Unfortunately, you can't catch up with everything he says, you can't just drop the subject as he is talking about material to be included in the final exam. You feel self-conscious about interrupting him, but as you are becoming increasingly worried about failing in the exam, you decide to ask him to slow down. You say:

- Could you please be less faster than before ? (Interrogative)

$$
-407-
$$


You can catch up everything, can't you? (Question Tag)

Did you understand everything from the teacher? (Past simple)

Would you mind becoming increasingly worried about failing in the exam? (Embedded "if" clause)

Deciding to ask the teacher to slow down, is it o.k.? (ing forms conditional) 


\section{Communicative Skills Post-Test}

Name:

Class :

Dear pupils,

The following is a communicative test, try to respond to it, the way you understand.

\section{3-"Request" Situation}

You are attending a class when you find that you have run out of paper and you need to take some important notes. You ask your friend for some spare papers but he/she doesn't have any either. On looking behind, you notice a new classmate who has just transferred to your class. You don't know his/her name but you need some papers, so you have no choice but you have to ask her for some. You say:

- Could you please give me time to take some important notes? (Interrogative)

You asked your friend to hurry for some spare papers, didn't you? (Question Tag) 
What did you notice behind you with your new classmate? (Past simple)

You transferred to another place and you don't know its name, why? (Embedded "if" clause)

Deciding to ask your classmate for some help. (ing forms conditional)

\section{4-"Request" Situation}

You are a team leader and working on a new project when you get an urgent phone call from a friend. You really need to take a note and a phone number but don't have a pen. A couple of girls who joined your team very recently have a pen on their table. You really need that pen and decide to interrupt them and ask if you can borrow it. You say:

- Could you please help me to be a team leader ? (Interrogative)

You get an urgent phone call from a friend, Don't you? (Question Tag)

\section{$-410-$}


Educational and Psychological Studies Faculty of Education Journal Zagazig University Vol. (36) No. (113), Part(2), October 2021

You didn't have a pen or a table, what did you need? (Past simple)

Would you mind joining couple of girls with the team? (Embedded "if" clause)

Deciding to interrupt the team and asking them if they can follow you? (ing forms conditional) 